\title{
Predation on a Nicobar Frog, Amnirana nicobariensis (Stoliczka 1879), by a Nicobar Bronzeback, Dendrelaphis humayuni (Tiwari and Biswas 1973), from Great Nicobar Island, Republic of India
}

\author{
V. Rangasamy ${ }^{1}$, C. Sivaperuman ${ }^{1}$, and Khan Ashaharraza ${ }^{2 *}$
}

'Zoological Survey of India, Andaman and Nicobar Regional Centre, Port Blair- 744 102, Andaman and Nicobar Islands, India (rangasamymu@gmail.com) ${ }^{2}$ Research Administrator, Indian Herpetological Society, Pune- 411 009, Maharashtra, India (ashaharrazakhan@gmail.com) *corresponding author

$T^{3}$ he Andaman and Nicobar Islands contribute substantially to the diversity of India's flora and fauna, introducing Indo-Malayan, Indo-Chinese, and Oceanic elements to the biota (Das 1996; Gadgil 1997). Young Czech naturalistexplorer, Ferdinand Stoliczka (1838-1874) made the first systematic herpetological collection from these islands (Das 1999). At about the same time, Blyth (1846) wrote the first account of the vertebrate fauna.

The Nicobar Bronzeback (Dendrelaphis humayuni) is an uncommon, diurnally active, arboreal snake that is endemic to Great Nicobar Island, the southernmost and the largest of the Nicobars (Vijayakumar and David 2006). Tiwari and Biswas (1973) described the species on the basis of specimens collected by Humayun Abdul Ali (Biswas and Sanyal 1977). Little is known about the natural history of this island endemic. The Nicobar Frog (Amnirana nicobariensis) is widely distributed across southeastern Asia (Frost 2018) and has been recorded in northeastern India (Sen 2004; Sarkar and Ray 2006), the Nicobar Islands (Das 1994), Borneo,
Siberut, Sumatra, Java, Bali, Indonesia (Diesmos et al. 2009), and peninsular Thailand through peninsular Malaysia (Taylor 1962; Berry 1975; Frith 1977).

At 1446 h on 17 March 2018, during a visit to the Great Nicobar Biosphere Reserve (709'58.8”N, 9344'57.5”E), we encountered an adult male Dendrelaphis humayuni (total length $-900 \mathrm{~mm}$ ) on the forest floor amidst Bamboo (Bambusa sp.) leaf litter (Fig. 1a) in the Campbell Bay National Park (Fig. 2). The snake struck an Amnirana nicobariensis on the left flank before slowly moving its grip toward the head (Fig. 1b). Although colubrids usually swallow frogs alive and without constriction (Mori 1994), this frog was dead before the snake began swallowing it. Total time from the initial strike to completion was $15 \mathrm{~min}$.

\section{Acknowledgements}

We are grateful to Kailash Chandra (Director, Zoological Survey of India) for permitting us to conduct a study at the Great Nicobar Biosphere Reserve, Gernot Vogel (Society

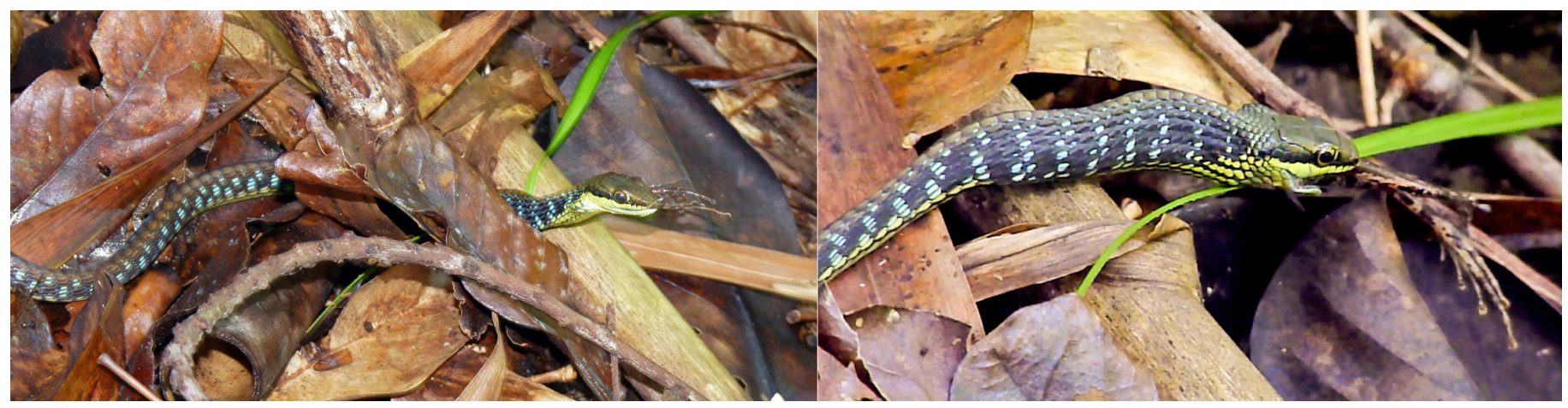

Fig. 1. A Nicobar Bronzeback (Dendrelaphis humayuni) swallowing a Nicobar Frog (Amnirana nicobariensis) in the Campbell Bay National Park, Great Nicobar Biosphere Reserve, Great Nicobar Island, India. Photographs by V. Rangasamy. 


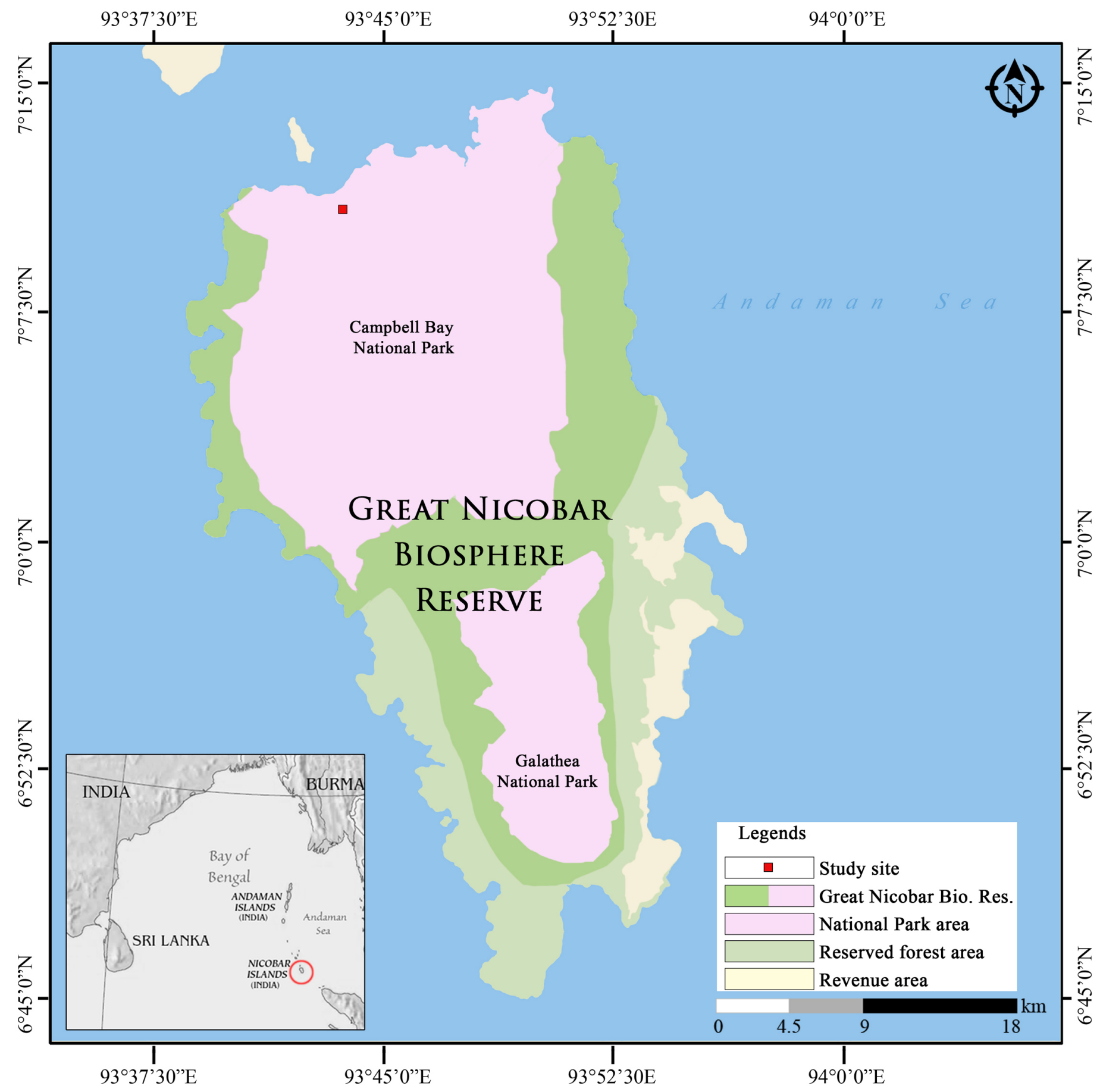

Fig. 2. Map showing the study site where a Nicobar Bronzeback (Dendrelaphis humayuni) swallowed a Nicobar Frog (Amnirana nicobariensis) in the Campbell Bay National Park, Great Nicobar Biosphere Reserve, Great Nicobar Island, India.

for South Asian Herpetology) for valuable insights, and Anil Khaire (Chairman, Indian Herpetological Society) for help with the literature.

\section{Literature Cited}

Berry, P.Y. 1975. The Amphibian Fauna of Peninsular Malaysia. Tropical Press, Kuala Lumpur, Malaysia.

Biswas S. and D.P. Sanyal. 1977. Notes on the Reptilia collection from the Great Nicobar Island during the Great Nicobar Expedition in 1966. Records of the Zoological Survey of India 72: 107-124.
Blyth, E. 1846. Notes on the fauna of the Nicobar Islands-Reptilia. Journal of the Bombay Natural History Society 15: 367-379.

Das, I. 1994. A checklist of amphibians and reptiles of the Andaman and Nicobar Islands. Journal of Andaman Science Association 10: 44-49.

Das, I. 1996. Biogeography of Reptiles of South Asia. Krieger Publishing Company, Malabar, Florida.

Das, I. 1999. Biogeography of the Amphibians and Reptiles of the Andaman and Nicobar Islands, pp. 43-77. In: H. Ota (ed.), Tropical Island Herpetofauna: Origin, Current Diversity and Conservation. Elsevier Science Ltd., Amsterdam, The Netherlands.

Diesmos, A., D. Iskandar, P.P. van Dijk, R. Inger, I. Das, and S.P. Vijayakumar. 
2009. Amnirana nicobariensis. The IUCN Red List of Threatened Species 2009: e.T58281A89362139 (http://www.iucnredlist.org/details/58281/0).

Frith, D.W. 1977. A preliminary list of the Amphibia of Phuket Island and adjacent mainland, Peninsular Thailand. Natural History Bulletin of the Siam Society 26: 189-199.

Frost, D.R. 2018. Amnirana nicobariensis. Amphibian Species of the World: An Online Reference. Version 6.0. American Museum of Natural History, New York (http://research.amnh.org/vz/herpetology/amphibia/Amphibia/Anura/ Ranidae/Amnirana/Amnirana-nicobariensis).

Gadgil, M. 1997. Diversity - The Cornerstone of Life. The National Council for Science and Technology Communication, New Delhi, Vigyan Prasar, Noida, and Sanctuary Magazine, Mumbai.

Mori, A. 1991. Effects of prey size and type on prey-handling behavior in Elaphe quadrivirgata. Journal of Herpetology 25: 160-166.

Sen, N. 2004. Further notes on state wise distribution of the amphibian fauna of north east India. Records of the Zoological Survey of India 102: 105-112.

Sarkar, A.K. and S. Ray. 2006. Amphibia. Zoological Survey of India, Fauna of Arunachal Pradesh, State Fauna Series 13: 285-316.

Taylor, E.H. 1962. The amphibian fauna of Thailand. University of Kansas Science Bulletin 43: 267-599.

Tiwari K. K. and S. Biswas. 1973. Two new reptiles from Great Nicobar Island. Journal of the Zoological Society of India 25: 57-63.

Vijayakumar, S.P. and P. David. 2006. Taxonomy, natural history, and distribution of the snakes of the Nicobar Islands (India), based on new materials and with an emphasis on endemic species. Russian Journal of Herpetology 13: 11-40. 